\title{
Towards Sustainable Agribusiness and Food Security in Kenya
}

\author{
Joram Ngugi Kamau \\ Department of Agricultural Economics \\ Egerton University-Kenya
}

How to cite this paper: Kamau, J. N.. (2019) Towards Sustainable Agribusiness and Food Security in Kenya. International Journal of Food Science and Agriculture, 3(2), 136-138.

DOI: $10.26855 /$ ijfsa.2019.06.001

*Corresponding author: Kamau, J. N., Department of Agricultural Economics, Egerton University-Kenya.

Email: ngugij88@gmail.com

\begin{abstract}
Population and climate change in Kenya is exerting pressure on the agricultural production in a country juxtaposed by diminishing and deteriorating conditions of arable land. Land segmentations and subdivision is posing a threat to food security in Kenya and Africa as a continent. While the damage of land subdivision cannot be reversed in Kenya due to the nature of land tenure system, something must be done to guarantee present and future food security in the country. This paper introduces the land use consolidation model in which farmers in the same geographical proximity exercises production of a common produce based on their ecological comparative advantage. The essence of this model is to ensure that farmers benefit from economies of scale. The assumption is; small scale farmers, in the same proximity and producing similar products, ideally act as large scale farmers. In this land consolidation model, farmers can optimize on producing products which they have an absolute advantage and trade on what they have production inefficiency. Intra counties trade could be facilitated by the revival of the railway system whose capacity has been unheeded. In this scenario, water harvesting becomes economical in guarantying a complete cycle of farm produces through irrigation. It's therefore imperative that the government embarks on massive water harvesting through dams to complement rain fed agriculture and hence ensure a continuous cycle of farm products for consumption and raw materials for agro processing industries in value addition. The objective of this is to ensure that there is constant supply of agricultural products in the country to combat the perennial food insecurity and spur industrialization in the country.
\end{abstract}

\section{Keywords}

Land use consolidation; Comparative advantage; Irrigation; Food insecurity

\section{Introduction}

The nature of farming in Kenya is that of an amalgamation of mixed farming where farmers produce an assortment of crops and livestock that can literally survive in their ecological zones regardless of their production capacity. While the author is cognitive of the role of agricultural diversification in curbing food security, the era of agricultural gambling is long gone. The axiom of comparative advantage postulates that a country should strictly engage in production of goods and services in which they have an absolute advantage.

Kenya is an agricultural country with more than $70 \%$ of employment opportunities provided by agriculture either directly or indirectly. How agricultural activities are conducted in the country provokes some serious debates. According to Fischer and Qaim (2012) [1], in the highlands of Kenya for example, the average land ownership is 1 acre. These are the small scale farmers. In this parcel, half an acre is apportioned to farming in which every type of crop and animal must be accommodated.

Brokers and middle men have been the spell towards agricultural expansion in the country (Krone et al., 2016) [2]. Majority of farmers being small scale farmers, they fall prey to abuse by the middle men. There are no standard metric measures for agricultural produces and therefore produces are priced based on mutual agreement where the farmer is always at the sword edge due to the nature of the produces as well as the economic situations of the farmers. 
While the debate for manufacturing in the country is imminent, agro processing industries should be on the rise to take advantage of the unexploited opportunities in value addition. With differential in ecological zones, varieties of industries should be positioned at every sub county of the 47 counties in the country to catalyze agricultural productivity in the country due to availability of ready market for farm produces.

\section{Discussions}

Land consolidation is a phenomenon that allows bulk production of similar products in the same geographical location (Deininger and Byerlee 2011) [3]. While land subdivision is a reality, this model proposes on a phenomenon where small scale farmers in the same geographical location and proximity should be encouraged to collectively produce a single produce in which the region has a comparative advantage. Water harvesting in the country should be a priority by both the national and county governments regardless of whether agriculture is a devolved unit of the county governments.

With unpredictable weather patterns in Kenya, climate smart agriculture should be embraced to guarantee food security in the country and the continent at large. Farming does not require rain; it requires water and therefore complete dependence on rain fed agriculture in Kenya should be discouraged especially when the weather conditions are becoming errant and unpredictable. This has occasioned field loses to farmers hence reducing the total output from the farms. To supplement rain fed agriculture, irrigation is inevitable to ensure an all cycle of farm produces in the country.

While investment in water dams in the country is an expensive venture by the government, farmers should embrace land use consolidation based on their comparative advantages. In this, farmers in the same geographical proximity should practice production of a similar crop. By doing so, individual small scale farmers tend to form a regional block of production and therefore enjoys the economies of production scale.

Kenya has eight major regional blocks with different ecological conditions. By having these regional production blocks with different comparative advantages, trade sets in. Farmers produce what they are efficient in and buy the rest from other production blocks in the country. Overreliance of rain fed agriculture is proving futile due to climate change. Demand for farm products is ever on the rise while the production land is either declining or deteriorating hence the urgency to correct the irreversible mistake of land subdivision.

With agricultural segmentations in the country, value addition of agricultural produces would be a milestone in agricultural industrialization. While the multiplier effect of value addition cannot be underestimated, the direct impact of this is a catalyst towards a turnaround investment in agriculture and agricultural technological innovations.

\section{Conclusions}

The theory of the firm posits that producers are rational and their motive is to maximize the return on investment. Recently, adoption of agribusiness in the country is taking new dimensions through technology and innovations. With the recent trends in global warming, reliance on rain fed agriculture in Kenya should be discouraged through massive water harvesting during the downpours. Water reservoirs ensure a continuous cycle of agricultural production throughout the year.

With regional specialization in agro enterprise, blocks will produce what they have a comparative advantage in. Trade will set in and therefore invites competition in production due to availability of ready market for farm products. Production of high value crops; whose production takes less than four months, should be prioritized to ensure maximum return on investments.

Since land subdivision mutilation is irreversible in the country, geographical proximity should be an asset for farmers to achieve production efficiencies. By extending production scale, farmers are able to overcome market failures such as information asymmetry and transaction costs. Farmers will enjoy the benefits of economies of scale in both production and marketing of their produces.

While farmers are victims of information asymmetry both at the production and marketing levels, production segmentation ensures moral hazards and transaction costs are minimized. Mechanization of agriculture will be possible through land consolidation and therefore ensure farmers enjoy economies of scale in production and hence maximize on their investment return. Blocks should take advantage of local universities and technical institutions in their area to ensure knowledge based agriculture where technology is a priority.

\section{Recommendations}

With the reality of climatic change dawning in the country, smart farming; which incorporates land consolidation, comparative advantage, irrigation and use of modern technologies is inevitable if the country is to be food secure. A combination of comparative advantage, land consolidation and irrigation will ensure that agriculture becomes a lucrative business in the country hence becoming a pull factor for young and new entrepreneurs. It's imperative therefore, that stakeholders be informed 
of the urgency in combating climatic change and land tenure dynamics in the country.

It's a fallacy to ignore the multiplier effect of agriculture in the economy. The Kenyan government should therefore invest in dams especially in the rural areas where agriculture is on its death bed. Mega projects such as standard gauge railway and affordable housing are necessary but not sufficient to guarantee economic takeoff. Priority should be to pump these colossal amounts into agricultural investments in which the country has a comparative advantage in. Ensure presence of government excavators at each sub county so that any farmer can subcontract at an affordable cost to excavate a mini dam in his or her farm. Facilitate the small scale farmers and allow the axiom of multiplier effect take its course in stimulating economic growth in the country.

\section{References}

[1] Fischer, E., \& Qaim, M. (2012). Linking smallholders to markets: determinants and impacts of farmer collective action in Kenya. World Development, 40(6), 1255-1268.

[2] Krone, M., Dannenberg, P., \& Nduru, G. (2016). The use of modern information and communication technologies in smallholder agriculture: Examples from Kenya and Tanzania. Information Development, 32(5), 1503-1512.

[3] Deininger, K., \& Byerlee, D. (2011). The rise of large farms in land abundant countries: Do they have a future?. The World Bank. 